\title{
Activation of phenoxazinone synthase expression in Streptomyces lividans: characterization of the activator fragment from Streptomyces antibioticus
}

\author{
Farah S. Fawaz'† and George H. Jones ${ }^{2}$ \\ Author for correspondence: George H. Jones. Tel: +1 404727 4208. Fax: +1 4047272880.
}

\footnotetext{
1 Department of Biology, The University of

Michigan, Ann Arbor, MI 48109, USA

2 Department of Biology, Emory University, Atlanta, GA 30322, USA
}

\begin{abstract}
We have isolated an active $719 \mathrm{bp}$ fragment from the $4.3 \mathrm{~kb}$ region of the genome of Streptomyces antibioticus that activates a silent phenoxazinone synthase (PHS) gene in Streptomyces lividans. Sequencing of the 719 bp fragment revealed several potential open reading frames (ORFs); however, the distribution of $\mathbf{G}+\mathbf{C}$ in these putative ORFs was uncharacteristic of streptomycete genes. No RNA products transcribed from the active sequence were detected by dot-blot hybridization and no proteins corresponding in size to the predicted products from the ORFs were observed when appropriate plasmids were used as templates in a streptomycete coupled transcriptiontranslation system. Fragments of 249 and 243 bp, respectively, were obtained from the 719 bp fragment from $S$. antibioticus and from the $S$. lividans genome by PCR cloning. Both fragments activated phs in S. lividans when cloned on a high copy number plasmid.
\end{abstract}

Keywords: silent genes, Streptomyces, antibiotic, actinomycin, phenoxazinone synthase

\section{INTRODUCTION}

Actinomycins are chromopeptide antibiotics produced by several different actinomycetes (Waksman, 1968). The enzymes involved in activation of the precursor of the actinomycin chromophore and in polymerization of the amino acids of the pentapeptide chains have been isolated and characterized (Keller et al., 1984; Keller, 1987; Keller \& Schlumbohm, 1992; Stindl \& Keller, 1993). In the pathway for actinomycin biosynthesis in Streptomyces antibioticus, phenoxazinone synthase (PHS) may catalyse the penultimate step, namely the oxidative condensation of two molecules of 4-methyl 3-hydroxyanthraniloyl pentapeptide lactone to generate actinomycinic acid (Katz $\&$ Weissbach, 1962). The structural gene for PHS ( $p h s A$ ) has been cloned in $S$. lividans, an organism that does not normally produce either PHS or actinomycin D (Jones \& Hopwond, 1984a). Another cloned sequence, $4.3 \mathrm{~kb}$ in size and also derived from $S$. antibioticus, was shown to activate an otherwise silent phs gene in S. lividans (Jones \&

\footnotetext{
†Present address: Department of Medicine, Division of Infectious Diseases, University of California, San Francisco, CA 94143, USA.

Abbreviation: PHS, phenoxazinone synthase.

The GenBank accession number for the sequence ( 719 bp insert from pJSM550) reported in this paper is $L 14560$.
}

Hopwood, 1984b). The silent gene has been cloned in Escherichia coli (Madu \& Jones, 1989).

Cryptic genes have been defined as phenotypically silent DNA sequences that are not normally expressed during the life cycle of an organism but which can be activated as a result of rare genetic events such as point mutations, transposition of a mobile genetic element or recombination (Hall et al., 1983). These cryptic genes are retained through cycles of decryptification and cryptification in response to environmental changes (Hall et al., 1983). Silent genes, on the other hand, have been defined as unexpressed genes originating from duplications that do not confer a phenotype, and which are therefore not subject to selection pressure (Beacham, 1987). The $p h s$ gene from $S$. lividans will be referred to as silent since no PHS activity has been detected except upon the introduction of the $S$. antibioticus $4.3 \mathrm{~kb}$ sequence.

Several mechanisms by which the $4.3 \mathrm{~kb}$ sequence could activate the phs gene of $S$. lividans can be envisaged. The sequence could code for a protein or RNA activator that acts at the transcriptional or translational level, or even at the post-translational level (for example by modifying an inactive PHS precursor). Alternatively, the $4.3 \mathrm{~kb}$ sequence could act as an operator capable of titrating a repressor in the mycelium, resulting in the derepression of phs. 
To characterize further the $4.3 \mathrm{~kb}$ sequence and distinguish between these possibilities, we used a subcloning analysis followed by DNA sequencing, dot-blot assays of total RNA and the use of an in vitro coupled transcriptiontranslation system. Our results indicate that no protein or RNA gene product is needed to activate the silent gene in $S$. lividans. Furthermore, the activating sequence has been localized to a $249 \mathrm{bp}$ fragment with a region of strong; dyad symmetry; disruption of this region destroys the activation phenotype.

\section{METHODS}

Organisms, growth conditions and plasmids. The S. lividans 66 derivative TK24 (Hopwood et al., 1983) was cultured and used to prepare protoplasts and transformed as described previously (Hopwood et al., 1985; Jones \& Hopwood, 1984a, b). The PHS assay was done with mycelium grown on galactose-glutamic acid (GGA) agar (Gallo \& Katz, 1972). Replicate PHS assays varied by no more than $4 \%$.

Recombinant plasmids used or developed in the present study are listed in Table 1. E. coli strains XL1-Blue-2 (rec A1 end A1 gyr.A96 thi-1 bsDR17 supE44 relA1 lac $\left[\mathrm{F}^{\prime}\right.$ pro $A B$ lac ${ }^{a} Z \Delta \mathrm{M} 15$ Tn10 (tetR)]; Bullock et al., 1987) and M147 (dam dcm gal ara lac thr leu thi ton $A$ tsx rpsL supE), obtained from Brian Spratt, University of Sussex, UK, were cultured in L broth and L agar.

DNA isolation and manipulation. Plasmid and chromosomal DNAs were prepared and manipulated as described in earlier publications (Hopwood et al., 1985; Jones \& Hopwood, 1984a, b).

PCR cloning. Primers for the polymerase chain reaction were obtained from the DNA Synthesis Core at the Biomedical Research Core Facilities of the University of Michigan. The sequences of primers $\mathrm{pB} 1$ and $\mathrm{pB} 2$ were $5^{\prime} \mathrm{GAGGCATGCT} T$ CGTGACGATCATGAA3' and 5'GAGTGATCATGAACCCGCTTGCTGAT3', respectively. The underlined bases represent an $S p b$ I site in the case of $\mathrm{pB} 1$ and a $B c / \mathrm{I}$ site in the case of pB2. PCR was done as described in Gould et al. (1989) using $1 \mu \mathrm{g}$ of each of the primers, and $200 \mathrm{ng}$ in the case of plasmid DNA or $1 \mu \mathrm{g}$ of genomic template DNA. pJSM550 (Table 1) was used as the template for the synthesis of the $S$. antibioticus sequence spanning the two BamHI sites of the 719 bp BclI-SpbI fragment of pIJ2502 (Fig. 1b, c). The same primers were used in a PCR reaction with $S$. lividans genomic DNA as the template. The PCR reaction products were digested in turn with $S p h I$ and $B c /$, then cloned into the modified $\mathrm{KS}+$ and $\mathrm{SK}+$ Bluescript vectors that harbour both sites and propagated in $E$. coli M147, a dam strain unable to methylate $B c l$ sites. (The $B c l I$ and $S, b h I$ sites in the vectors were obtained by inserting $B c l$ and $S p b I$ linkers in the $S m a \mathrm{I}$ and EcoRV sites of the polylinkers, respectively.) Once the desired clone was identified, that plasmid was retransformed into XL1-Blue-2 for DNA sequencing. The PCR products were released from the M147 derived recombinant plasmids and cloned between the BglII and SphI sites of pIJ702 in S. lividans.

DNA sequencing. DNA was sequenced by the chain termination method of Sanger $e t$ al. (1977) using a Sequenase kit as described by the supplier (United States Biochemical), combined in some cases with Taq polymerase (Khambaty \& Ely, 1990).

RNA isolation and dot-blot analysis. RNA was isolated from $48 \mathrm{~h}$ liquid cultures grown either in yeast extract/malt extract (YEME) medium supplemented with sucrose or in GGA medium as described in Hopwood et al. (1985) except that the high salt precipitation step was omitted. Thus the RNA preparations would be expected to contain both high and low molecular mass RNAs. Increasing amounts of RNA were then spotted on a Nytran membrane using a filtration manifold (Bio-

Table 1. Plasmids used or referred to in the present study

\begin{tabular}{|c|c|}
\hline Plasmid & Description \\
\hline $\begin{array}{l}\text { pBluescript } \\
\mathrm{KS}+, \mathrm{SK}+\end{array}$ & $\begin{array}{l}\text { Phagemid cloning vector (Stratagene). The } \\
\text { vector was modified by inserting linkers } \\
\text { containing sites for } B c l \mathrm{I} \text { or } S p h \mathrm{I}\end{array}$ \\
\hline pl J2501 & $\begin{array}{l}2.4 \mathrm{~kb} \text { phs structural gene }(p h s A) \text { from } S \text {. } \\
\text { antibioticus cloned into the } S p h I \text { site of } \\
\text { pIJ702 (Jones \& Hopwood, 1984a) }\end{array}$ \\
\hline pIJ2502 & $\begin{array}{l}4.3 \mathrm{~kb} \text { activating sequence cloned into the } \\
\text { SphI site of pl J702 (Jones \& Hopwood, } \\
1984 \mathrm{~b} \text { ) }\end{array}$ \\
\hline pIJ2505 & $\begin{array}{l}p h s A \text { cloned into the } S p h \text { I site of pBR } 322 \\
\text { (Jones \& Hopwood, 1984a) }\end{array}$ \\
\hline pIJ2506 & $\begin{array}{l}4.3 \mathrm{~kb} \text { activating sequence in pI J702 in the } \\
\text { opposite orientation to } \mathrm{pIJ} 2502\end{array}$ \\
\hline pJSM500 & $\begin{array}{l}\text { Approximately } 1.6 \mathrm{~kb} B g / \mathrm{II} \text { fragment from } \\
\text { pIJ } 2502 \text { cloned into the } B g \Omega \mathrm{II} \text { site of } \mathrm{pIJ} 702 \\
\text { (present study) }\end{array}$ \\
\hline pJSM510 & $\begin{array}{l}\text { Approximately } 2.4 \mathrm{~kb} B g / \mathrm{II}-\mathrm{Bam} \mathrm{HI} \text { fragment } \\
\text { from pI J2502 cloned into the } B g / \mathrm{II} \text { site of } \\
\text { pI J702 (present study) }\end{array}$ \\
\hline pJSM520 & $\begin{array}{l}\text { Approximately } 1 \mathrm{~kb} B c / \text { I fragment derived } \\
\text { from pI J2502 cloned into the } B g / I \mathrm{I} \text { site of } \\
\text { pI J702 (present study) }\end{array}$ \\
\hline pJSM521 & 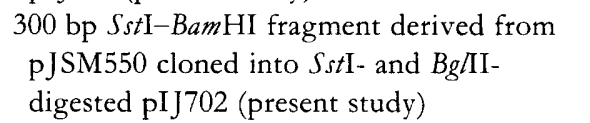 \\
\hline pJSM522 & $\begin{array}{l}180 \text { bp Bam HI fragment derived from } \\
\text { pJ SM550 cloned into the Bg/II site of } \\
\text { pIJ702 (present study) }\end{array}$ \\
\hline pJSM523 & $\begin{array}{l}298 \text { bp BamHI-SphI fragment from } \\
\text { pJSM550 cloned into Bg/II- and } S p b I- \\
\text { digested pIJ702 (present study) }\end{array}$ \\
\hline pJSM524 & $\begin{array}{l}249 \text { bp S. antibioticus PCR product cloned } \\
\text { between the BgIII and SphI sites of pl J702 } \\
\text { (present study) }\end{array}$ \\
\hline pJSM525 & $\begin{array}{l}243 \text { bp S. lividans } \text { PCR product cloned } \\
\text { between the BgIII and SpbI sites of pI J702 } \\
\text { (present study) }\end{array}$ \\
\hline pJSM550 & $\begin{array}{l}719 \text { bp BclI-SphI fragment from pIJ } 2502 \\
\text { cloned into BamHI- and SphI-digested, } \\
\text { modified KS + Bluescript vector (present } \\
\text { study) }\end{array}$ \\
\hline pJSM551 & $\begin{array}{l}719 \text { bp } B c I I-S p b I \text { fragment from pIJ } 2502 \\
\text { cloned into BamHI- and SpbI-digested, } \\
\text { modified SK + Bluescript vector (present } \\
\text { study) }\end{array}$ \\
\hline pJSM620 & $\begin{array}{l}\text { Approximately } 1 \mathrm{~kb} B c / \mathrm{I} \text { fragment derived } \\
\text { from pl J2502 cloned into the Bam } \mathrm{HI} \text { site } \\
\text { of the low copy number vector pl J922 } \\
\text { (present study) }\end{array}$ \\
\hline
\end{tabular}




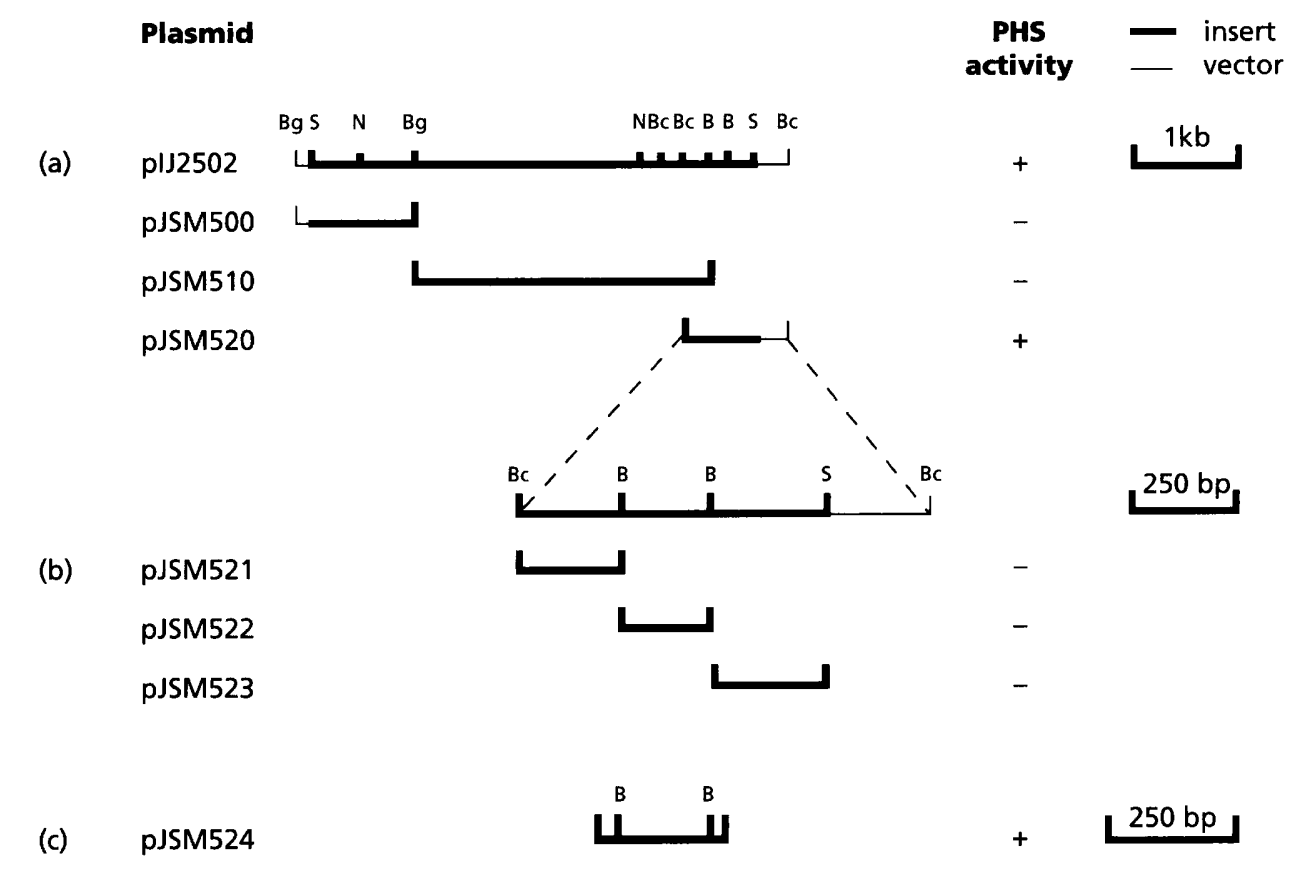

Fig. 1. (a) Subcloning strategy for the $4.3 \mathrm{~kb}$ sequence from the recombinant plasmid plJ2502. Plasmids pJSM500, pJSM510 and pJSM520 were constructed by inserting a $1.6 \mathrm{~kb}$ Bg/ll fragment, a $2.4 \mathrm{~kb}$ Bg/ll-BamHI fragment and an approximately 985 bp BC/l fragment, respectively, from plJ2502 into the Bg/ll site of the multicopy streptomycete vector plJ702. Individual clones containing each of the recombinant plasmids were assayed for PHS activity. Only pJSM520 was found to activate the silent phs gene from S. lividans. (b) Further subcloning of the pJSM520 insert in plJ702 to yield plasmids pJSM521, pJSM522 and pJSM523 resulted in loss of PHS activity. (c) Cloning of the region overlapping the two BamHI sites of plJ2502 using PCR. When reintroduced in S. lividans the PCR product was shown to activate phs. B, BamHI; $\mathrm{BC}, \mathrm{BCll}$; Bg, Bg/ll; N, Ncol; S, Sphl. The bars at the extreme right of the figure indicate the size scale for the cloned fragments represented in (a), (b) and (c).

Rad). Filters were prehybridized overnight and hybridized for $40 \mathrm{~h}$ at $68{ }^{\circ} \mathrm{C}$ with ${ }^{32} \mathrm{P}$-labelled probes as described previously (Jones \& Hopwood, 1984a, b).

In vitro coupled transcription-translation. Reaction mixtures for coupled transcription-translation typically contained $2 \cdot 25 \mu \mathrm{g}$ of template DNA, the other components indicated by Thompson et al. (1984) and $\left[{ }^{35} \mathrm{~S}\right]$ methionine. Samples were analysed by denaturing polyacrylamide gel electrophoresis and fluorography exactly as described by Jones \& Hopwood (1984a).

Miscellaneous methods. PHS was assayed as described previously (Choy \& Jones, 1981; Jones \& Hopwood, 1984a). Protein was determined as described by Bradford (1976). The copy number of pJSM620 was estimated by fractionation of total DNA from $S$. lividans transformants on $\mathrm{CsCl}$ (Hopwood $e t$ al., 1985), using a value of $10000 \mathrm{~kb}$ as the size of the $S$. lividans genome (Goodfellow \& Cross, 1983).

\section{RESULTS}

\section{Identification of a region of the $4.3 \mathrm{~kb}$ insert retaining the ability to activate PHS expression}

The sequence responsible for activating PHS expression in $S$. lividans was localized to a specific region of the $4.3 \mathrm{~kb}$ fragment cloned in pIJ2502 from S. antibioticus. Advantage was taken of several restriction sites in $\mathrm{pIJ} 2502$ that furnished fragments that could be cloned in the $B g / I I$ site of pIJ702. These experiments (Fig. 1 and Table 2) identified a $985 \mathrm{bp} \mathrm{BclI}$ fragment that retained the ability to activate phs (the insert of pJSM520, Fig. 1a). The fragment, which contained $266 \mathrm{bp}$ from $\mathrm{pIJ} 702$ and $719 \mathrm{bp}$ from the $4.3 \mathrm{~kb}$ insert of $\mathrm{pIJ} 2502$ (Jones \&

Table 2. PHS activity of subclones of plJ2502

PHS activity was measured as described in Methods. Specific activities (averages of three replicates) were calculated as in Choy \& Jones (1981).

\begin{tabular}{|lc|}
\hline Plasmid & $\begin{array}{c}\text { Enzyme } \\
\text { specific activity } \\
\text { [nmol } \text { min }^{-1} \\
\text { (mg protein) }^{-1} \text { ] }\end{array}$ \\
\hline pIJ702 & ND \\
pIJ2501 & $52 \cdot 44$ \\
pIJ2502 & $2 \cdot 33$ \\
PJSM520 & $1 \cdot 19$ \\
pIJ922 & ND \\
pJSM620 & $1 \cdot 89$ \\
pJSM524 & $0 \cdot 71$ \\
pJSM525 & $0 \cdot 42$ \\
\hline
\end{tabular}

ND, No PHS activity detected. 


\begin{tabular}{|c|c|c|c|c|}
\hline$B C .1 \mathrm{I}$ & 20 & - & 40 & \\
\hline GATCACGTC & GTTTTCGCA & CGTGAGCCAC & GCCACCGGCG & GGGCG \\
\hline 60 & 70 & 80 & 90 & \\
\hline GCCAAAGA & CACCGGAAG & GGACGTCCGC & AGGA & 2 \\
\hline 110 & & 130 & & \\
\hline GCCCGTCG & CGAGGACCG & CCGCGAGCAA & GACCA & GTT \\
\hline 60 & 170 & 180 & 190 & \\
\hline ICGACAGAT & СATTAATTGT & CCGGATCGCG & GGT & C \\
\hline 210 & 220 & Or & 240 & \\
\hline $\mathrm{TT}$ & SGT & $h I$ & & \\
\hline 260 & Or & $f 2 \longrightarrow 280$ & 290 & \\
\hline $\mathrm{CCCCAC}$ & GCAT & $\mathrm{rcccc}$ & GC & \\
\hline 0 & 20 & 30 & 10 & \\
\hline GCCGGCC & CG & TGC & CG & 1 \\
\hline 0 & & 30 & 0 & \\
\hline GGGGTACGC & GCTGTTCGCC & CAGCA & $\mathrm{CCA}$ & . \\
\hline & 0 & 0 & 10 & \\
\hline $\begin{array}{l}\mathrm{C} \\
0\end{array}$ & C & $\begin{array}{r}\text { SCCG } \\
480\end{array}$ & $\begin{array}{r}\text { CGCC } \\
490\end{array}$ & \\
\hline $\begin{array}{r}\text { STGCGGGC } \\
510\end{array}$ & $\begin{array}{r}\text { GGCGATCCAC } \\
520\end{array}$ & $\begin{array}{r}\text { CGACC } \\
530\end{array}$ & CCAGC & $\begin{array}{l}\text { ACTCCAG } \\
\text { Or }\end{array}$ \\
\hline ICGCTGCGG & G & ACGT & CGTG & $x$ \\
\hline 560 & 0 & 580 & 590 & \\
\hline $\begin{array}{r}\text { ACGGACGG } \\
610\end{array}$ & $\begin{array}{r}\text { CGCTGGA } \\
620\end{array}$ & $\begin{array}{r}\text { CGGA } \\
630\end{array}$ & $\begin{array}{r}\text { SGAG } \\
640\end{array}$ & $\operatorname{Arx}$ \\
\hline $\begin{array}{r}\text { PCG } \\
660\end{array}$ & $\begin{array}{r}\text { ACACCGCG } \\
670\end{array}$ & $\begin{array}{r}\text { CCGCGCTGGC } \\
680\end{array}$ & $\begin{array}{r}\text { CACC } \\
690\end{array}$ & 2.5 \\
\hline $\begin{array}{r}710 \\
710 \text { TACCGG }\end{array}$ & $\begin{array}{r}\text { CCCTCGGC } \\
720\end{array}$ & $\begin{array}{r}\text { S2CC } \\
730\end{array}$ & $\begin{array}{l}740 E \\
\text { PeAc }\end{array}$ & $B$ \\
\hline $\begin{array}{l}760 \\
78 C G \\
\end{array}$ & $\begin{array}{r}\text { CGGATCAT } \\
770\end{array}$ & $\begin{array}{r}\text { GGTC } \\
780\end{array}$ & $\begin{array}{r}\text { GGGA } \\
790\end{array}$ & reco \\
\hline $\begin{array}{r}\text { GAGATCAGC } \\
810\end{array}$ & $\begin{array}{r}\text { MAGCGGGTTC } \\
820\end{array}$ & $\begin{array}{r}\text { AGGACCAGGT } \\
830\end{array}$ & $\begin{array}{r}\text { GACGGCCCTG } \\
840\end{array}$ & ATCGC \\
\hline $\begin{array}{r}860 \\
8606 C\end{array}$ & $\begin{array}{r}\text { SCTGCTG } \\
870\end{array}$ & $\begin{array}{r}\text { GTGG } \\
880\end{array}$ & $\begin{array}{r}\text { GCACGTACGG } \\
890\end{array}$ & TAT \\
\hline $\begin{array}{r}\text { CGGTACT } \\
910\end{array}$ & TCCAG & $\begin{array}{l}\text { CATCAGCAGC } \\
- \text { Orf } 3930\end{array}$ & $\begin{array}{r}\text { CCCTCGCCGA } \\
940\end{array}$ & CCG \\
\hline $\begin{array}{r}\text { GGCCTG } \\
960\end{array}$ & $\begin{array}{r}\text { GTGGTAGTCG } \\
970\end{array}$ & $\begin{array}{r}\text { TGCATCCGGC } \\
980\end{array}$ & CTCGGT & CGC \\
\hline thest & $\mathrm{Cl}$ & דe & & \\
\hline
\end{tabular}

Fig. 2. Sequence of the $985 \mathrm{bp} B c / l$ activating fragment. The

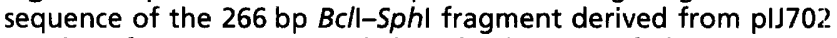
is taken from Bernan et al. (1985). The rest of the sequence (719 bp) was determined in the present study. The sequence is numbered starting at the recognition site for the restriction endonuclease $B c / l$ in pJSM520. Relevant restriction sites are indicated on the figure. The ATGs corresponding to putative ORFs 1-4 are shown and the terminator codons for each putative ORF are overlined. The $249 \mathrm{bp}$ sequence obtained by PCR cloning (Fig. 4) is shown in bold and the sequences of the: primers used for the PCR are italicized.

Hopwood, 1984b), was cloned into the $B g /$ II site of pIJ702 in the same orientation as in pIJ2502 (Fig. 1a) When this fragment was further subcloned to yield. recombinant plasmids pJSM521, pJSM522 and pJSM523 (Fig. 1b), the activation phenotype was lost.

\section{Effect of copy number on the activation of PHS}

To study the dosage effect on the activation of the $S$. lividans phs gene, the $985 \mathrm{bp} B c / \mathrm{I}$ fragment cloned from pIJ2502 in pJSM520 was subcloned into the low copy number plasmid pIJ922 to give pJSM620. pIJ922 is present at three to five copies per genome (Lydiate et al., 1985). S. lividans strains harbouring the vectors pI J702 or pIJ922 were used as negative controls. Transformants carrying the recombinant plasmid pIJ2501 (the pIJ702 derivative bearing the $p h s$ structural gene from $S$. antibioticus; Jones \& Hopwood, 1984a) were used as a positive control. Extracts of mycelium transformed with either the high or low copy number derivatives gave similar levels of PHS activity ('Table 2). Moreover, the observed values were comparable to the PHS specific activity in pIJ2502 transformants. We estimate the copy number of pJSM620 to be five to eight copies per chromosome.

\section{Sequence analysis}

Both strands of the $985 \mathrm{bp} \mathrm{BclI}$ fragment described above were sequenced on the average three to four times. The sequence of the vector-derived portion was as reported by Bernan et al. (1985). The sequence of the entire fragment is shown in Fig. 2. Similarly to other streptomycete sequences, the 719 bp $B c l I-S p h I$ fragment from $S$. antibioticus was found to be $74 \% \mathrm{G}+\mathrm{C}$. Four potential open reading frames (ORFs) of at least 26 codons were identified. The positions of the initiation and termination codons of the four ORFs (Fig. 2) are: ORF1 (ATG/ position 229, TAG/position 594); ORF2 (ATG/position 269, TGA/position 550); ORF3 (ATG/position 935, TGA/position 545); ORF4 (ATG/position 548, TGA/ position 240). A fifth ORF (ORF5) in frame with ORF1 but starting further upstream than ORF1 and with GTG as the start codon was also detected.

The putative ORFs would encode proteins with molecular masses between 10 and $21 \mathrm{kDa}$. ORF1 and ORF5 would require sequence information from the cloning vector (nt 1-266 of the BclI-SpbI fragment, Fig. 2) for expression. The sequence of ORF2 is completely contained in pJSM523 (Table 1); that plasmid, however, does not activate PHS expression in $S$. lividans. ORF1, ORF3, ORF4 and ORF5 were disrupted by further subcloning the $B c / I$ sequence into pJSM521, pJSM522 and pJSM523 (Fig. 1b). As shown in Table 3 , the $\mathrm{G}+\mathrm{C}$ distribution in ORFs $1-5$ is unlike that normally observed in streptomycete genes (Bibb et al., 1984). Finally, no similarity of the predicted products of ORFs $1-5$ to any protein in GenBank was discerned.

\section{S. lividans transformants do not contain messenger or structural RNAs related to the 719 bp fragment}

Total RNA was isolated from S. lividans mycelium transformed with pJSM520 or pIJ2501 (see Table 1). Cultures were grown for $48 \mathrm{~h}$ in YEME medium or, in some cases, in actinomycin production (GGA) medium. RNA from the pJSM520 derivative was probed with both pIJ702 and pJSM550; RNA from the pIJ2501 derivative was probed with pIJ2505. pIJ550 consisted of the active $B c l I-S p h I$ fragment in pBluescript KS $+($ Table 1$) \cdot$ pI J702 and $\mathrm{pIJ} 2505$ were used as positive controls; the former should detect the mRNA for the thiostrepton resistance gene (Thompson et al., 1982) as well as other messenger RNAs encoded by the plasmid (Kendall \& Cohen, 1988), and the latter should detect phs mRNA. Increasing amounts, up to $50 \mu \mathrm{g}$ of RNA from mycelium cultured on YEME or GGA, were spotted on a Nytran membrane. The appropriate DNA positive control was included in each case. As shown in Fig. 3(b), no signal was observed 

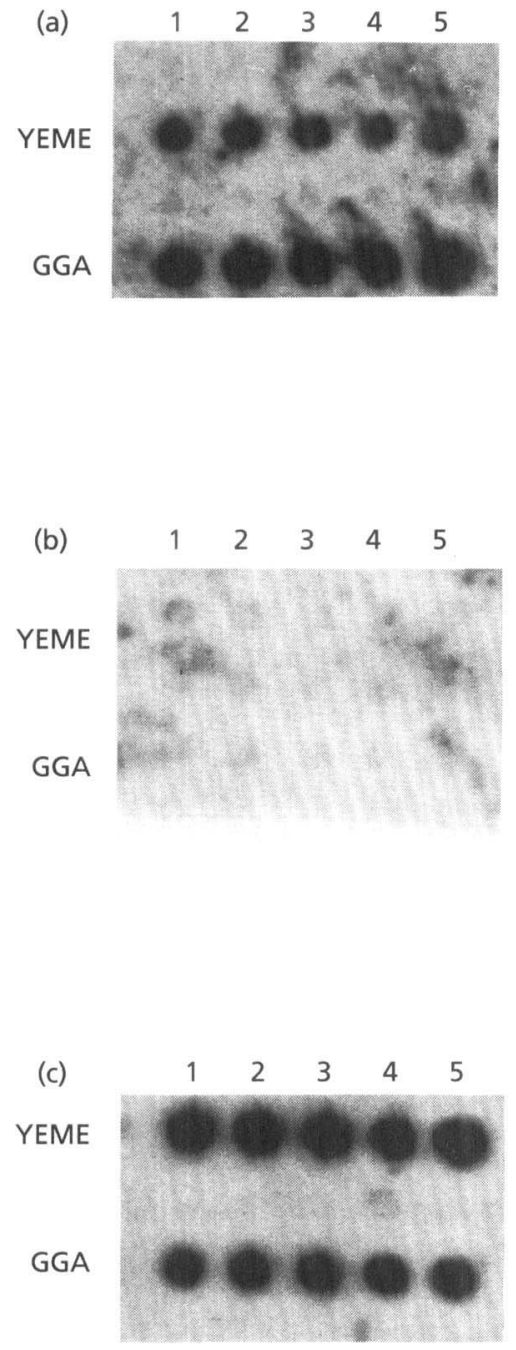

Fig. 3. Dot-blotting of total RNA from S. lividans transformed with pJSM520. Cells were cultured for $48 \mathrm{~h}$ in YEME or in GGA. Total RNA was prepared as described in Methods. Increasing amounts of RNA $(5,10,20,40$ and $50 \mu \mathrm{g})$ were analysed (lanes 1 through 5). RNA was probed with plJ702 (a), pJSM550 (b) and plJ2505 (c). Appropriate DNA positive controls were spotted on each filter (not shown). Further exposure (up to a week) did not modify the pattern observed above.

with RNA probed with PJSM550. Under the same conditions positive signals were obtained with the DNA control and with RNA from transformed S. lividans probed with pIJ702 (Fig. 3a) or pIJ2505 (Fig. 3c). The filters shown in Fig. 3 were overexposed to facilitate identification of any hybrids that might have been formed with pJSM550 as the probe (Fig. 3b). This probably accounts for the apparent failure of the signal strength to vary linearly with RNA concentration in Fig. 3(a, c). Exposure of the filters for even longer periods did not modify the results shown in Fig. 3.

To compare results from this experiment to a negative control, pBluescript $\mathrm{KS}+$ was used to probe the same amounts of RNA from $S$. lividans transformed with pJSM520 (data not shown). The appropriate DNA
Table 3. $\mathrm{G}+\mathrm{C}$ distribution in putative ORF codons

The table summarizes the occurrence of $G+C$ in the indicated codon positions for each of the four ORFs referred to in the text and for 27 Streptomyces genes (Seno \& Baltz, 1989).

\begin{tabular}{|c|c|c|c|}
\hline & \multicolumn{3}{|c|}{$\begin{array}{c}\text { Mol } \% \mathrm{G}+\mathrm{C} \text { at } \\
\text { given codon } \\
\text { position: }\end{array}$} \\
\hline & 1 & 2 & 3 \\
\hline ORF1 & $76 \cdot 2$ & $71 \cdot 9$ & $68 \cdot 5$ \\
\hline ORF2 & $68 \cdot 9$ & $71 \cdot 1$ & $81 \cdot 1$ \\
\hline ORF3 & $85 \cdot 7$ & $57 \cdot 1$ & $69 \cdot 1$ \\
\hline ORF4 & $73 \cdot 5$ & $85 \cdot 3$ & $70 \cdot 6$ \\
\hline Streptomyces & $69 \cdot 7$ & $49 \cdot 9$ & $90 \cdot 6$ \\
\hline
\end{tabular}

\begin{tabular}{|c|c|}
\hline SA & $\begin{array}{l}\text { GCATGCTTCG } \\
1111111111\end{array}$ \\
\hline SL & GCATGCTTCG \\
\hline SA & $\begin{array}{l}\text { GGACCCACCC } \\
\|\|\|\|\|1\|\end{array}$ \\
\hline SL & GGACCCACCC \\
\hline SA & $\begin{array}{l}\text { CGGCAACACC } \\
\|\|\|\|\|\|\end{array}$ \\
\hline SL & CGGCAACACC \\
\hline SA & $\begin{array}{l}\text { AGACCTACAC } \\
1111111111\end{array}$ \\
\hline SL & AGACCTACAC \\
\hline SA & $\begin{array}{l}\text { CACCCCGATC } \\
11\|\|\|1\| 1\end{array}$ \\
\hline SL & CACCCCGATC \\
\hline SA & $\begin{array}{l}\text { GTCAGCGCCG } \\
11111111 .\end{array}$ \\
\hline SL & GTCAGCGCCA \\
\hline SA & TTCATGATCA \\
\hline SL & TTCATGATCA \\
\hline
\end{tabular}

\begin{tabular}{|c|c|c|}
\hline $\begin{array}{l}\text { TGACGATCAT } \\
\text { IIIIIIIIIIIII } \\
\text { TGACGATCAT }\end{array}$ & $\begin{array}{l}\text { GAACACGGAC } \\
|1| \ldots|1| 1 \mid \\
\text { GAA--C-GAC }\end{array}$ & $\begin{array}{l}\text {-GGATCCGCT } \\
\text { - IIIIIIIIIII } \\
\text { GGGATCCGCT }\end{array}$ \\
\hline $\begin{array}{l}\text { GGACGAGAAG } \\
\text { IIIIIIIIIIII } \\
\text { GGACGAGAAG }\end{array}$ & $\begin{array}{l}\text { GAGATAGGCC } \\
|||.||||| \mid \\
\text { GAG-TAGGCC }\end{array}$ & $\begin{array}{l}\text { GGCCCTTCCG } \\
\text { IIIIIIII. } \\
\text { GGCCCTT-CG }\end{array}$ \\
\hline $\begin{array}{l}\text { GCGCCGCGCT } \\
111.111111 \\
\text { GCGGCGCGCT }\end{array}$ & $\begin{array}{l}\text { GGCGGGCCGC } \\
|\||\||\||\|\mid\| \\
\text { GGCGGGCCGC }\end{array}$ & $\begin{array}{l}\text { ACCTTCACCG } \\
111111111111 \\
\text { ACCTTCACCG }\end{array}$ \\
\hline $\begin{array}{l}\text { CGGCACCCTC } \\
\text { IIIIIIIII. } \\
\text { CGGCACCCT- }\end{array}$ & $\begin{array}{l}\text { GGCGCCTCGG } \\
111\|1\| 111 \\
\text { GGCGCCTCGG }\end{array}$ & $\begin{array}{l}\text { TCCGCGCGGT } \\
111.1111111 \\
\text { TCCACGCGGT }\end{array}$ \\
\hline $\begin{array}{l}\text { GAGGAGGGCG } \\
11111111111111 \\
\text { GAGGAGGGCG }\end{array}$ & $\begin{array}{l}\text { ACGGACGGAT } \\
\text { IIIIIIIIIIII } \\
\text { ACGGACGGAT }\end{array}$ & $\begin{array}{l}\text { CATCGGCCTG } \\
\text { 1IIIIIIIIIIIII } \\
\text { CATCGGCCTG }\end{array}$ \\
\hline $\begin{array}{l}\text { GGATCCGGGT } \\
\text { 11111111111111111110 } \\
\text { GGATCCGGGT }\end{array}$ & $\begin{array}{l}\text { CGAGGAGATC } \\
\text { IIIIIIIIIIII } \\
\text { CGAGGAGATC }\end{array}$ & $\begin{array}{l}\text { AGCAAGCGGG } \\
1111111111111 \\
\text { AGCAAGCGGG }\end{array}$ \\
\hline
\end{tabular}

Fig. 4. Sequence comparison of the $S$. antibioticus and $S$. lividans PCR products. SA, S. antibioticus; SL, S. lividans. Excluding the sequence of the two primers (included in this figure), the two sequences are $95 \%$ identical.

positive controls were also spotted on the filters. The two filters, probed with pBluescript KS + and with pJSM550, showed similar results after exposure for $3 \mathrm{~d}$ (data not shown). Exposure of the filters for $7 \mathrm{~d}$ still did not reveal RNAs that hybridized specifically to the pJSM550 insert. The results of these experiments have other implications. Since total RNA was probed with the insert of interest, RNA products such as rRNA and tRNA should have been detected. They were not. Similar results were obtained in control experiments like those just described but using the insert of pIJ2502 as the probe (data not shown). Moreover, no similarity to any known RNA was revealed when the 719 bp sequence was used to search GenBank.

Finally, in other experiments (not shown), using the streptomycete coupled transcription-translation system, 
the insert of PJSM520 did not encode polypeptides of sizes that corresponded to those of the putative ORFs described in the preceding section. Therefore, neither RNA nor protein products of the BclI-SphI fragment appear to be involved in the activation of $p h s$ in S. lividans.

It should be noted here that Southern Cross hybridization experiments (Potter \& Dressler, 1986) ruled out the possibility of rearrangement of the activating fragment or the region of the S. lividans genome corresponding to the activating fragment (Madu \& Jones, 1989) in transformants containing PIJ2502 (unpublished results).

\section{Only a 249 bp fragment derived from the Bcll sequence is necessary for the activation phenotype}

The results presented above suggested that the activating sequence overlapped one or both BamHI sites of pI J2502 (Fig. 1a). Since no convenient restriction sites for subcloning were available outside the two Bam HI sites, two primers were synthesized, each 26 bases long and containing 17 bases complementary to the sequence of interest (Fig. 2). The remaining bases were an $S p h \mathrm{I}$ site plus three randomly chosen bases for $\mathrm{pB} 1$, and a $B c l$ site plus three other random bases for $\mathrm{pB} 2$ (see Methods). The two primers were used along with the DNA template pJSM550 in a PCR reaction. The amplified region spanning the two BamHI sites was in turn cloned into pIJ702 to yield pJSM524. The relationship between the PCR fragment and the various subclones of $\mathrm{pIJ} 2502$ is shown in Fig. 1(c). Clones containing the PCR fragment were assayed for PHS activity. Results from this experiment indicated that the working hypothesis was correct and that this $249 \mathrm{bp}$ fragment was able to activate phs expression in S. lividans (Table 2).

The sequence of the PCR product was determined for four independent clones and compared with the sequence of the $719 \mathrm{bp}$ activator fragment. The cloned PCR fragment overlaps the rightmost (as depicted in Fig. 1) BamHI site of pJSM524. If the region around that site is required for the function of the activating fragment, the loss of the activation phenotype (Fig. 1b) upon cloning of the Bam HI fragment into the BgII site of pIJ702 would be explained. No sequence similar to the $249 \mathrm{bp}$ fragment was detected in GenBank.

\section{PCR cloning of a fragment from S. lividans with homology to the $S$. antibioticus activator fragment}

The two primers utilized in the previous experiment were used in a PCR reaction with S. lividans genomic DNA as the template. Annealing was done at $55^{\circ} \mathrm{C}$ and $65^{\circ} \mathrm{C}$; the second reaction gave a product with a mobility similar to the $S$. antibioticus product on a $1.6 \%$ agarose gel. The PCR product was in turn digested with $S p h \mathrm{I}$ and $B c / \mathrm{I}$ and cloned in E. coli M147 in the modified KS + and SK+ Bluescript vectors. The sequences of five different clones were determined and compared to the $S$. antibioticus sequence (Fig. 4). The two sequences were $95 \%$ identical and contained a region around one of the Bam HI sites that exhibited dyad symmetry. This sequence, which starts at

\section{S. antibioticus}

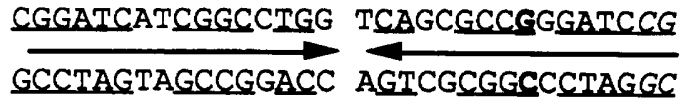

\section{S. lividans}

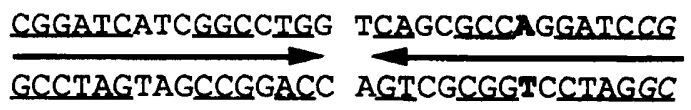

Fig. 5. Region of dyad symmetry (arrows) overlapping one of the two BamHI sites internal to the $S$. antibioticus and $S$. lividans PCR products. The two sequences are identical in both organisms except for a single bp change (bold). Two bases from one of the inverted repeats (italics) were lost when the BamHI fragment of plJ2502 was cloned to generate pJSM522. Complementary bases are underlined. plJ522 (Fig. 1) does not activate phs.

nucleotide 713 and ends at nucleotide 744 (Fig. 2), might generate a stable hairpin structure that could function as a protein recognition sequence. One of the differences between the $S$. lividans and $S$. antibioticus sequences occurs in the region of dyad symmetry; this renders the $S$. lividans structure potentially less stable because of one fewer GC bond in the stem region (Fig. 5).

The $243 \mathrm{bp}$ PCR product from S. lividans was cloned between the Bg/II and SphI sites of pIJ702 giving pJSM525. The recombinant plasmid was used to transform S. lividans protoplasts. The PHS specific activity in these transformants was lower than that observed in transformants containing the $S$. antibioticus PCR product and was also lower than the activities observed in transformants containing pIJ2502, pJSM520 or pJSM620. However, PHS activities were easily measured in transformants containing the PCR products and replicate assay results varied by no more than $4 \%$. The reasons for the decreased levels of PHS in transformants containing the PCR products is not known at present.

\section{DISCUSSION}

Interest in the activation of the silent phs gene from $S$. lividans emerges from several interesting observations. First, PHS activity was detected in a number of streptomycetes, producers as well as non-producers of actinomycin $\mathrm{D}$, upon transformation with the recombinant plasmid pIJ2502 (Jones \& Hopwood, 1984b). Second, it was shown by both cloning (Madu \& Jones, 1989) and Southern hybridizations that sequences similar to the PHS structural gene and the $4.3 \mathrm{~kb}$ activator fragment exist in the genomes of these organisms. These findings raised the exciting possibility that silent genes or even pathways for antibiotic production are present in members of this group. Streptomycetes possess a large genome, of the order of $8000-10000 \mathrm{~kb}$ (Goodfellow \& Cross, 1983; Kieser et al., 1992; Leblond et al., 1993). Perhaps a significant fraction of these genomes harbour silent 
biosynthetic and resistance genes for antibiotics that are not normally produced. If so, the reason for and mechanism of their silencing is as yet unexplained. The identification of silent genes in S. lividans may lead to answers to the questions posed by these observations.

The data presented above suggest that the silent $p h s$ gene in S. lividans is not activated directly through a protein or RNA product of the activator fragment. Even though the $B c l$ sequence that activates $p h s$ includes four potential ORFs, FRAME analysis (Bibb et al., 1984) showed that none had the properties expected of a streptomycete gene. Moreover, no protein products of the precise size predicted by the ORF analysis were found with an in vitro coupled transcription-translation system, and no sequence-specific messenger RNA was detected in a dotblot assay of total RNA, even though phs expression in $S$. lividans was activated by this sequence. The data presented are more consistent with a model in which the cloned $249 \mathrm{bp}$ sequence activates $p h s$ in S. lividans by interacting with a negatively acting DNA-binding protein; it would be similar to an operator-repressor system. Introduction of the cloned sequence would titrate the DNA-binding protein and activate $p h s$ expression in S. lividans. If this model is correct, the DNA-binding protein must be present in only a few copies per chromosome since cloning the activator fragment on a low copy number plasmid vector leads to $p h s$ activation in $S$. lividans (Table 1). Gel retardation experiments are in progress to examine this hypothesis.

When the two BamHI sites present in the pIJ2502 insert were used for subcloning, no PHS activity was detected in $S$. lividans transformants. This suggests that sequences around one or both sites are necessary for activation (Fig. 1). We speculate that the region of dyad symmetry observed near one of the two sites (Fig. 5) is involved in binding the putative repressor. Interestingly, this $32 \mathrm{bp}$ long region is identical in $S$. antibioticus and $S$. lividans except for a single base pair. We have preliminary data suggesting the presence of a protein in S. lividans which binds to the 243 and $249 \mathrm{bp}$ activator fragments (unpublished results). However, confirmation of the importance of this region in protein binding must await the results of further subcloning, purification of the putative protein, DNase footprinting experiments and sitedirected mutagenesis.

While the mechanism of activation of the silent $p h s$ gene in $S$. lividans appears thus far to be novel in the genus Streptomyces, similar systems are present in enteric bacteria. Thus, the cel operon of E. coli $\mathrm{K} 12$, which is involved in the utilization of $\beta$-glucoside sugars, consists of five genes, cel $A B C D F$, and is cryptic because it is in a constant state of repression (Parker \& Hall, 1990a, b). The product of $c e l D$ is a negative regulatory protein that prevents expression of the wild-type cel operon. Activation of this operon results from point mutations in $c e l D$, or from insertions in an upstream regulatory sequence, presumably the sequence normally recognized by the repressor product of $c e l D$. The putative presence of such a system in $S$. lividans may indicate that the phenomenon of cryptic and silent genes is as widespread among streptomycetes as in other micro-organisms.

\section{ACKNOWLEDGEMENTS}

These studies were supported in part by grant R01 AI24202 from the National Institute of Allergy and Infectious Diseases and by grants from the University of Michigan and Emory University. The authors thank Ms Chuin-Ju Hsieh for carrying out the coupled transcription-translation assays.

\section{REFERENCES}

Beacham, I. R. (1987). Silent genes in prokaryotes. FEMS Microbiol Rev 46, 409-417.

Bernan, V., Filpula, D., Herber, W., Bibb, M. J. \& Katz, E. (1985). The nucleotide sequence of the tyrosinase gene from Streptomyces antibioticus and characterization of the gene product. Gene 37, 101-110.

Bibb, M. J., Findlay, P. R. \& Johnson, M. W. (1984). The relationship between base composition and codon usage in bacterial genes and its use in the simple and reliable identification of proteincoding sequences. Gene 30, 157-166.

Bradford, M. M. (1976). A rapid and sensitive method for the quantitation of microgram quantities of protein utilizing the principle of protein-dye binding. Anal Biochem 72, 248-254.

Bullock, W. O., Fernandez, J. M. \& Short, J. M. (1987). XL1-Blue: A high efficiency plasmid transforming $\operatorname{rec} A$ Escherichia coli strain with $\beta$-galactosidase selection. BioTechniques 5, 376-378.

Choy, H. A. \& Jones, G. H. (1981). Phenoxazinone synthase from Streptomyces antibioticus: purification of the large and small enzyme forms. Arch Biochem Biophys 211, 55-65.

Gallo, M. \& Katz, E. (1972). Regulation of secondary metabolite biosynthesis: catabolite repression of phenoxazinone synthase and actinomycin formation by glucose. $J$ Bacteriol 109, 659-667.

Goodfellow, M. \& Cross, T. (1983). In The Biology of the Actinomycetes, pp. 102-104. Edited by M. Goodfellow, M. Mordarski \& S. T. Williams. London: Academic Press.

Gould, S. J., Subramani, S. \& Scheffer, E. (1989). Use of the DNA polymerase chain reaction for homology probing: isolation of partial cDNA or genomic clones encoding the iron-sulfur protein of succinate dehydrogenase from several species. Proc Natl Acad Sci US A 86, 1934-1938.

Hall, B. G., Yokoyama, S. \& Calhoun, D. H. (1983). Role of the cyptic genes in microbial evolution. Mol Biol Evol 1, 109-124.

Hopwood, D. A., Kieser, R., Wright, H. M. \& Bibb, M. J. (1983). Plasmids, recombination and chromosome mapping in Streptomyces lividans 66. J Gen Microbiol 129, 2257--2269.

Hopwood, D. A., Bibb, M. J., Chater, K. F., Kieser, T., Bruton, C. J., Kieser, H. M., Lydiate, D. J., Smith, C. P., Ward, J. M. \& Schrempf, H. (1985). Genetic Manipulation of Streptomyces. A Laboratory Manual. Norwich: John Innes Foundation.

Jones, G. H. \& Hopwood, D. A. (1984a). Molecular cloning and expression of the phenoxazinone synthase gene from Streptomyces antibioticus. J Biol Chem 259, 14151-14157.

Jones, G. H. \& Hopwood, D. A. (1984b). Activation of phenoxazinone synthase expression in Streptomyces lividans by cloned DNA sequences from Streptomyces antibioticus. J Biol Chem 259, 14158-14164.

Katz, E. \& Weissbach, H. (1962). Biosynthesis of the actinomycin chromophore; enzymatic conversion of 4-methyl 3hydroxyanthranilic acid to actinocin. J Biol Chem 237, 882-886. 
Keller, U. (1987). Actinomycin synthetases: multifunctional enzymes responsible for the synthesis of the peptide chains of actinomycin. $J$ Biol Chem 262, 5852-5856.

Keller, U. \& Schlumbohm, W. (1992). Purification and characterization of actrinomycin synthetase I, a 4-methyl-3-hydroxyanthranilic acid-AMP ligase from Streptomyces chrysomallus. J Biol Chem 267, 11745-11752.

Keller, U., Kleinkauf, H. \& Zocher, R. (1984). 4-Methyl-3-hydroxyanthranilic acid activating enzyme from actinomycin-producing Streptomyces chrysomallus. Biocbemistry 23, 5852-5856.

Kendall, K. J. \& Cohen, S. N. (1988). Complete nucleotide sequence of the Streptomyces lividans plasmid pIJ101 and correlation of the sequence with genetic properties. I Bacteriol 170, 4634-4651.

Khambaty, F. M. \& Ely, B. (1990). A method for the determination of sequence of high $\mathrm{G}+\mathrm{C} \%$ DNA by the sequential application of Sequenase and Taq polymerase. BioTecbniques 9, 714-716.

Kieser, H., Kieser, T. \& Hopwood, D. A. (1992). A combined genetic and physical map of the Streptomyces coelicolor A3(2) chromosome. J Bacteriol 174, 5496-5507.

Leblond, P., Redenbach, M. \& Cullum, J. (1993). Physical map of the Streptomyces lividans 66 genome and comparison with that of the related strain Streptomyces coelicolor A3(2). J Bacteriol 175, 3422-3429.

Lydiate, D. J., Malpartida, F. \& Hopwood, D. A. (1985). The Streptomyces plasmid SCP2*: Its functional analysis and development into useful cloning vectors. Gene 35, 223-235.

Madu, A. C. \& Jones, G. H. (1989). Molecular cloning and in vitro expression of a silent phenoxazinone synthase gene from Streptomyces lividans. Gene 84, 287-294.

Parker, L. L. \& Hall, B. G. (1990a). Characterization and nucleotide sequence of the cryptic cel operon of Escherichia coli K12. Genetics 124, 455-471.

Parker, L. L. \& Hall, B. G. (1990b). Mechanisms of activation of the cryptic cel operon of Escherichia coli K12. Genetics 124, 473-471.

Potter, H. \& Dressler, D. (1986). A 'Southern Cross' method for the analysis of genome organization and the localization of transcription units. Gene 48, 229-239.

Sanger, F., Nicklen, S. \& Coulson, A. R. (1977). DNA sequencing with chain terminating inhibitors. Proc Natl Acad Sci USA 74, 5463-5467.

Seno, E. T. \& Baltz, R. H. (1989). Structural organization and regulation of antibiotic biosynthesis and resistance genes in actinomycetes. In Regulation of Secondary Metabolism in Actinomycetes, pp. 1-48. Edited by S. Shapiro. Boca Raton, FL: CRC Press.

StindI, A. \& Keller, U. (1993). The initiation of peptide formation in the biosynthesis of actinomycin. J Biol Chem 268, 10612-10620.

Thompson, C. J., Skinner, R. H., Thompson, J., Ward, J. M., Hopwood, D. A. \& Cundliffe, E. (1982). Biochemical characterization of resistance determinants cloned from antibiotic-producing streptomycetes. J Bacteriol 151, 678-685.

Thompson, J., Rae, S. \& Cundliffe, E. (1984). Coupled transcriptiontranslation in extracts of Streptomyces lividans. Mol \& Gen Genet 195, 39-43.

Waksman, S. A. (1968). Actinomycin-Nature, Formation and Activities. New York: Wiley Interscience.

Received 13 July 1993; revised 22 October 1993; accepted 15 November 1993. 